\title{
A CONSTRUÇÃO DO EU NAS NARRATIVAS DE VIDA
}

\author{
THE SELF-CONSTRUCTION FORMATION IN LIFE NARRATIVES
}

LA CONSTRUCCIÓN DEL YO EN LAS NARRATIVAS DE VIDA

\author{
KAREN WORCMAN ${ }^{I}$ \\ André Oliveira Costa ${ }^{\text {II }}$
}

REsumo Neste artigo, analisamos a construção do Eu nas narrativas de vida a partir das perspectivas da sociologia de Norbert Elias e da psicanálise de Sigmund Freud. De início, fazemos uma breve leitura da constituição do Eu, segundo N. Elias, a partir de sua leitura de S. Freud para, em seguida, pontuarmos como o processo de produção de uma narrativa de vida pode significar, para um narrador, um exercício de construção do Eu. Nesta análise, utilizamos alguns conceitos oriundos da história oral para apresentar a narrativa de vida como um documento historicamente construído. Por fim, analisamos duas histórias de vida que fazem parte do acervo do Museu da Pessoa para comparar de que forma indivíduos de contextos socioculturais muito diferentes constroem, em suas narrativas, visões de si e da sociedade.

Palavras-chave: Norbert Elias; Psicanálise; História Oral; Museu da Pessoa; NarraTIVAS DE VIDA.

Abstract In this article we use the perspective of Norbert Elias's sociology and Sigmund Freud's psychoanalysis to analyze the construction of the self in life stories narratives. We, first, present how the self is built as viewed by Norbert Elias after Freud and then, we discuss how the construction of a life story narrative can be understood as one strong strategy for creating the idea of the self. Our analysis take on some concepts from oral history and we based it on 2 life stories of the archive of the Museu da Pessoa. We compare how individuals of different cultural and social background have different understanding of their selves, though both of them have a self-concept present in their narratives.

Keywords: Norbert Elias; Psychoanalysis; Oral History; Museum of the Person; Life STORIES.

\footnotetext{
${ }^{\mathrm{I}}$ Museu da Pessoa

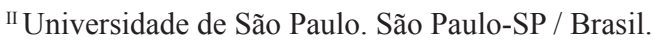


Resumen En este artículo analizamos la construcción del Yo en las narrativas de vida a partir de las perspectivas de la sociología de Norbert Elias y del psicoanálisis de Sigmund Freud. Al principio, hacemos una breve lectura de la constitución del Yo, según N. Elias a partir de su lectura de S. Freud para luego puntuar como el proceso de producción de una narrativa de vida puede significar, para un narrador, un ejercicio de construcción del Yo. En este análisis utilizamos algunos conceptos oriundos de la historia oral para presentar la narrativa de vida como un documento histórico e históricamente construido. Por último, analizamos dos narrativas de vida que forman parte del acervo del Museo de la Persona para comparar de qué forma individuos de contextos socioculturales muy diferentes construyen, en sus narrativas de vida, visiones de sí y de la sociedad.

Palavras clave: Norbert Elias; Psicoanálisis; Historia Oral; Museo de la Persona; NARRATIVAS DE VIDA.

\section{A construÇão do Eu}

A sociologia de Norbert Elias rompe com a dicotomia "indivíduo" e "sociedade", que se encontra presente em inúmeras formas de pensar. Essa dicotomia, segundo Elias aponta em A sociedade de corte (1996), é parte da tradição do pensamento ocidental moderno e efeito do processo civilizador das sociedades de corte, que resultou nos movimentos de separação e exclusão das camadas sociais. Dessa forma, essa dicotomia veio sendo construída desde o século XVI e do mesmo processo civilizador resultaram outras disjunções, como mente/corpo, razão/emoção, verdade/ilusão, público/privado, que até os dias atuais permanecem nas distinções entre os campos de conhecimento como antagonismos intransponíveis. Conforme Elias afirma no segundo volume de sua obra $O$ processo civilizador, o indivíduo não pode ser considerado como uma entidade autônoma, estática e isolada dos outros. Em oposição a esse ser fechado, o homo clausus, temos um indivíduo aberto que se constitui por meio de laços invisíveis de interdependência com outros indivíduos:

\footnotetext{
A imagem do homem como 'personalidade fechada' é substituída aqui pela 'personalidade aberta', que possui um maior ou menor grau (mas nunca absoluto ou total) de autonomia face à de outras pessoas e que, na realidade, durante toda a vida é fundamentalmente orientada para outras pessoas e dependente delas. A rede de interdependência entre os seres humanos é o que os liga (ELIAS, 1993, p. 249).
}

Por sua vez, a psicanálise de Sigmund Freud, que foi uma referência teórica fundamental para o pensamento de N. Elias, como ele próprio declarou em diversos momentos de sua obra (ELIAS, 1993; 2000), buscou transpor a dualidade entre "indivíduo" e "sociedade" para sustentar uma relação de imbricação entre esses termos. Freud, em Psicologia das massas e análise do eu, por exemplo, reconhece mudanças comportamentais nos indivíduos que fazem parte de uma massa, na medida em que eles acabam por se identificarem mutuamente com valores e ideais que estruturam as organizações sociais, assim como faz 
uso das explicações próprias aos processos inconscientes dos indivíduos para compreender os fenômenos das massas. Nesse sentido, também as massas funcionam conforme a lógica da economia psíquica dos indivíduos, de modo que a figura do líder e os ideais da massa, que regulam os comportamentos, dominam "[...] o Eu no lugar do ideal do Eu [...]" (FREUD, 2011a, p. 91).

Norbert Elias e Sigmund Freud nos mostraram que nem os indivíduos são estruturas isoladas dos laços sociais, nem as sociedades são superestruturas independentes das economias psíquicas dos indivíduos. Podemos identificar na obra de ambos um esforço para desenvolver a imbricação entre as estruturas sociais e as estruturas psíquicas. Em sua primeira pesquisa, A sociedade de corte, escrita na década de 1930, mas publicada apenas no final da década de 1960, Norbert Elias (1996) analisa a formação do Eu a partir da discursividade própria da sociedade de corte francesa dos séculos XIV a XVII. A identificação de cada pessoa com rituais, cerimoniais e etiquetas eram modos de os indivíduos se diferenciarem daqueles que não faziam parte do mesmo nível social. Nesse caso, quem internalizava as regras sociais na forma de autocontrole e controlava a expressão espontânea das emoções e dos comportamentos, por meio da criação de hábitos inconscientes, conseguia distinguir-se das pessoas que não faziam parte do mesmo círculo social e garantir condições de privilégio e prestígio. $\mathrm{O} \mathrm{Eu}$, nesse sentido, era formado a partir da posição social que cada um assumia dentro da sociedade.

Elias se volta para a análise de um tempo longínquo da História para mostrar que nossas configurações sociais atuais seguiram o modelo da sociedade de corte. O processo de formação do Eu, por meio da internalização de regras sociais na forma de Supereu, transmite inconscientemente a luta por um lugar de destaque na sociedade. Hábitos e costumes são formados para identificar o indivíduo como pertencente a determinada camada social. Nesse sentido, Elias (1993) analisa a origem de certos habitus: o uso de utensílios quando comemos, como garfo, faca e guardanapo, ou a maneira como nos vestimos e dormimos. A racionalidade cortesão, isto é, a discursividade da sociedade de corte, determina o modo de ser dos indivíduos por intermédio da configuração de suas economias psíquicas, moldando os processos inconscientes que conduzem os destinos da pulsão.

Por sua vez, a psicanálise de Freud também mostrou que o Eu não é uma instância psíquica inata, na medida em que ela é efeito dos processos de identificação que os indivíduos estabelecem uns com os outros. Nesse sentido, o Eu é constituído pelos discursos e narrativas nos quais o indivíduo encontra-se inserido desde o seu nascimento. Em $O$ Eu e o Id, Freud descreve o Eu como uma superfície onde se encontram as pulsões corporais, que constituem o Id, e o mundo externo, que envolve o indivíduo. De acordo com Freud (2011b, p. 26): “[...] o caráter do Eu é um precipitado dos investimentos objetais abandonados, de que contém a história dessas escolhas de objeto [...]”. O Eu, desse modo, é constituído pela história das marcas das relações com outros indivíduos. Entre esses registros de memória, um deles é especial, pois leva à formação de outra instância psíquica. Trata-se do Supereu, a primeira identificação que o indivíduo estabelece com seu pai, isto é, o registro da primeira representação das regras sociais, que determinam aquilo que o indivíduo pode ou não pode ser. 
Norbert Elias retoma a discussão e a leva a outro patamar para a sociologia, na medida em que integra os processos individuais com as estruturas sociais. Conforme ele descreve em A sociedade dos indivíduos, não é possível que um indivíduo se afirme como uma pessoa, referindo-se a si próprio como "eu", sem que ele, com isso, faça referência também às outras pessoas do discurso: tu, ele, nós e eles. Afirma Elias (1994a, p. 57): “[...] cada pessoa só é capaz de dizer 'eu' se e porque pode, ao mesmo tempo, dizer 'nós"'. A partir dos conceitos da psicanálise de Freud, a sociologia eliasiana postula que não existe um indivíduo independente de suas relações sociais, visto que a tendência no curso do processo civilizador é de internalizar a sociedade na forma de Supereu, enquanto instância psíquica que representa as regras e as coerções impostas pela sociedade. É possível verificar, em textos como Mudanças na Balança Nós-Eu, que Elias não nega a presença de um Eu individual em culturas que denomina "primitivas", mas o peso dessa relação tendia para o registro do Nós:

\footnotetext{
Se considerarmos a relação entre a identidade-eu e a identidade-nós, poderemos dizer que em todos os países, tanto mais quanto menos desenvolvidos, as duas estão presentes, mas nos primeiros é mais forte a ênfase na identidade-eu, enquanto nos últimos ela recai sobre a identidade-nós pré-nacional, seja ela a família, a aldeia nativa ou a tribo (ELIAS, 1994b, p. 147).
}

A teoria do processo civilizador, que considera as transformações sociais sempre a longo prazo, parte da análise dos comportamentos sociais dos indivíduos entre a Idade Média e o nascimento dos Estados-nação na Europa, identificando uma direção à maior diferenciação entre os indivíduos, ao aumento da complexidade das relações sociais, assim como o aumento no grau de identificação entre eles. Isso significa que no curso do processo civilizador a coerção externa tende a passar à autocoerção, o que implica indivíduos cada vez mais afastados uns dos outros, à estabilidade e ao autocontrole dos sentimentos e dos comportamentos, além do aumento do escopo de identificação entre as pessoas (MENNELL, 1992).

Além disso, tanto Elias quanto Freud localizam as tensões entre o Id, o Eu e o Supereu como um fenômeno característico do homem civilizado. É nesse contexto que ambos percebem a origem dos conflitos modernos. Enquanto Elias (1993, p. 283) afirma que "[...] o campo de batalha foi, em certo sentido, transportado para dentro do indivíduo. Parte das tensões e paixões que antes eram liberadas diretamente na luta de um homem com outro terá agora que ser elaborada no interior do ser humano". Freud (2010, p. 74), por sua vez, postula que na luta entre "[...] as duas tendências, a de felicidade individual e a de união com outros seres, têm de lutar uma com a outra no interior de cada indivíduo; assim os dois processos, de evolução individual e cultural, precisam defrontar-se e disputar um ao outro o terreno". Elias e Freud colocam que o mal-estar da civilização é resultado da internalização simbólica, pelo indivíduo, das coerções sociais.

O postulado de Norbert Elias contribui para compreender de que maneira uma história de vida pode traduzir o processo de construção do Eu. Se entendemos que toda e qualquer história de vida é uma construção ativa do Eu pelo narrador e que nela a sociedade está presente 
sob a forma do "sentido" à sua própria trajetória, poderemos compreender por que o fato de narrar a própria história possui grande potencial de impacto pessoal e social. Mas, se Elias atribui esse processo à formação do homem ocidental contemporâneo, como será então que um indivíduo que se encontra em outro contexto constrói seu Eu em sua narrativa de vida?

$\mathrm{Na}$ comparação entre narrativas de vida que faremos a seguir, um dos entrevistados é parte integrante do processo cultural civilizador europeu descrito por Elias. O outro, no entanto, emerge de uma realidade social brasileira bastante peculiar, porém, não deixou de ser orientado por um processo civilizador ocidental. Nosso interesse de análise é identificar possíveis diferenças nos processos de construção e narração do Eu de acordo com diferentes contextos sociais. E se existem, que diferenças seriam essas? Há diferenças na relação entre os processos de sociais e o processo de constituição do indivíduo em cada uma dessas narrativas? O que afinal, é história de vida?

\section{NARRATIVIDADE E HISTORIOGRAFIA}

O pensamento de Norbert Elias abre caminho para a interdisciplinaridade dos campos de saber, inscrevendo em uma mesma investigação, temas que dizem respeito à educação, à sociologia, à história, à psicanálise e à antropologia. O indivíduo e a sociedade são diferentes faces da mesma estrutura, enquanto que as configurações sociais são marcadas por relações de interdependência e poder. Nesse sentido, sua obra é caracterizada como uma sociologia configuracional a qual nos conduz à reflexão quanto à formação do indivíduo situada no social e a formação social correlacionada ao indivíduo. Nessa perspectiva, podemos identificar nas narrativas de si elementos, como poder, controle, infância, habitus, que conjugam a formação individual e os processos coletivos.

As pesquisas de Norbert Elias têm alicerce nas biografias como formas de compreender a constituição do Eu e dos processos sociais. Nessa linha, situamos, por exemplo, o livro que Elias escreveu sobre a vida de Mozart, apontando a imbricação entre o indivíduo e a sociedade: "Mozart só emerge claramente como um ser humano quando seus desejos são considerados no contexto de seu tempo" (ELIAS, 1994c, p. 15). Também os estudos sobre o rei Luís XIV, em A sociedade de corte (1996), foram feitos com vistas a compreender o funcionamento de dominação e interdependência da sociedade de corte. Devemos resistir a retirar o indivíduo de seu contexto social e apontá-lo como um ser livre e autônomo, como por vezes fazem as pesquisas historiográficas, e também resistir a considerar as estruturas sociais como sistemas que funcionam independente dos indivíduos, conforme a sociologia costuma operar em suas investigações.

Por isso preferiu-se aqui o conceito de figuração. Podemos dizer: "Uma corte é uma figuração de indivíduos" sem violentar o uso das palavras. Assim, de fato fica atenuada a dificuldade que sempre reaparece na história da teoria sociológica, com certa regularidade, tanto no caso das teorias que dirigem a atenção para os indivíduos como tais, quanto no daquelas que a dirigem para a sociedade como tal; uma dificuldade que acaba levando a disputas pendentes entre si (ELIAS, 1996, p. 155). 
O termo história de vida possui inúmeros significados e pode corresponder a processos bastante diversos entre si. Assumimos que a história de vida de um indivíduo aponta não para a sua existência singular, nem para o contexto social onde ele foi criado, mas para a imbricação entre essas duas condições. Assim, como afirma Hallbwachs (1968), é fundamental levar-se em consideração os quadros sociais e os contextos históricos que permeiam a construção de histórias de vida de quaisquer indivíduos ao mesmo tempo em que devemos considerar a singularidade presente em cada pessoa. É nessa soma de fatores (sociais, históricos e pessoais) que reside, ao nosso ver, a grande riqueza das histórias de vida. Nesse sentido, pensamos que seja possível uma análise figuracional também a partir dos relatos que se fazem sobre a vida dos indivíduos e, especialmente, no modo como eles próprios narram e constroem suas histórias de vida. As histórias de vida abrem espaço para a construção do Eu em interlocução com as transformações sociais.

As histórias às quais nos referimos neste artigo fazem parte do acervo do Museu da Pessoa, museu virtual e colaborativo de histórias de vida, fundado em São Paulo, em 1991, com o objetivo de transformar histórias de vida em fonte de conhecimento, conexão e compreensão entre pessoas. Como Organização da Sociedade Civil de Interesse Público (OSCIP), sem fins lucrativos, o Museu da Pessoa desenvolveu, ao longo de sua trajetória, diversas estratégias de atuação para garantir a sua sustentabilidade e ampliação de seu impacto social.

Atualmente, o Museu da Pessoa possui um acervo de cerca de 18 mil histórias de vida de brasileiros e brasileiras de todos os gêneros, idades, classes sociais, atividades e regiões do país. $\mathrm{O}$ acervo possui, ainda, cerca de 60 mil fotos e documentos catalogados junto aos entrevistados. A "casa" do Museu da Pessoa, um portal ${ }^{1}$ que dá acesso a esse material, permite também que cada pessoa envie sua história, monte sua coleção e busque o conteúdo que lhe interesse. Nos últimos 25 anos, o Museu da Pessoa realizou cerca de 250 projetos de memória em parceria com instituições, empresas, comunidades, escolas e setores do Governo. Os projetos responderam, em grande parte, pela constituição de seu acervo e resultaram em 74 publicações, 76 exposições e a organização de diversos centros de memória. Com foco na ampliação de seu impacto social, a metodologia sistematizada pelo Museu da Pessoa foi transformada em tecnologia social.

O livro Tecnologia Social da Memória (WORCMAN, GARDE-HANSEN, 2016) reúne práticas, conceitos e princípios essenciais para que pessoas, comunidades e instituições de diversas naturezas possam apropriar-se da metodologia de registro e produção de suas memórias. O processo inclui três módulos de trabalho - construir, organizar e socializar histórias - e começa com cada pessoa contando, organizando e socializando sua própria história para, em seguida, conectar essa história com outras do seu grupo que terminam por articular-se em uma rede mais ampla de histórias que compõem a sociedade atual. $\mathrm{O}$ processo de construção de histórias de vida a partir de entrevistas é um dos pilares da tecnologia social de memória. Nesse sentido, a metodologia desenvolvida pelo Museu da Pessoa tem como origem a História oral.

1 www.museudapessoa.net 
As entrevistas realizadas no Museu da Pessoa têm como base a metodologia de história oral, mais precisamente no que tange ao que Portelli (2016, p. 18) define como sendo a "arte da escuta". No entanto, o foco da tecnologia social de Memória do Museu da Pessoa é o próprio entrevistado e suas escolhas. O conteúdo produzido em uma história de vida traduz, segundo essa concepção, o que cada indivíduo filtra em sua memória como tendo especial significado. O "fato" por trás da história narrada não é, portanto, o objetivo da entrevista. O foco é o próprio indivíduo e a forma como lida com sua memória e produz, a partir desta, seu relato individual. Nesse sentido, é importante ressaltar que o resultado de uma entrevista é uma cocriação entre entrevistado e entrevistador. Segundo Thompson (2002), a história oral reintroduziu-se na academia a partir do uso de gravadores e trouxe uma séria discussão sobre seu valor como fonte histórica. A história oral é polêmica nos meios acadêmicos até hoje, tanto pela questão da subjetividade presente nos depoimentos quanto pela relação entre o que se denomina micro e macro história. O livro de Paul Thompson (2002) abarca bem essa questão. Podemos, contudo, afirmar que o que de fato diferencia a história oral das outras disciplinas históricas é que, de todas as práticas historiográficas, ela é precisamente aquela que cria uma fonte histórica, isto é, o registro de uma narrativa na história oral é a construção de uma fonte histórica única e inédita até aquele momento. E que tipo de fonte é essa?

Talvez a principal característica desse tipo de fonte - os depoimentos - não seja a subjetividade - tão questionada por algumas linhas da historiografia -, mas a singularidade da narrativa, isto é, o fato de que cada narrativa constitui uma articulação, singular, feita por alguém. Trata-se de uma narrativa que traduz - sempre - a perspectiva pessoal que o indivíduo tem sobre a própria experiência ou sobre um tema específico. O mais precioso de um depoimento é a articulação (as relações de causa e efeito, os destaques, os comentários) que cada narrador faz para construir sua própria história. Essa articulação traz a singularidade de cada um. É um equívoco ver/perceber o narrador apenas como um representante de um dado segmento social ou contexto histórico.

A narrativa é sempre um olhar, uma perspectiva, uma “[...] enunciação de sentidos no qual o que de fato aconteceu, além de inacessível por natureza, é também o não procurado [...]" (DE CERTEAU, 2015, p. 34). Deslocar o discurso de Michel de Certeau sobre o fazer historiográfico para entender a produção das histórias de vida é simbólico em duas vertentes: a primeira porque assume-se a potencialidade destas como "fontes históricas" e, a segunda, porque podemos atribuir, a cada pessoa, o papel de um "historiador" de si. Pode-se argumentar, no entanto, que o historiador possui, por trás de seu trabalho, um quadro teórico construído conscientemente e que, não necessariamente, o narrador e seu entrevistador estão cientes desse processo. Isto é inegável. No entanto, isto não impossibilita tomarmos de empréstimo conceitos e dinâmicas do "fazer histórico" para compreender o processo de construção de um "documento histórico" (assumido aqui com toda sua subjetividade): a história de uma vida.

Construir uma narrativa sobre si é colocar o outro no lugar de testemunho de sua existência. Nesse sentido, a construção do Eu só se faz por meio da mediação do indivíduo 
com uma alteridade, que pode confirmar ou não as propriedades que o definem como um indivíduo pertencente a determinado contexto social. Conforme a psicanalista Ana Costa aponta em seu livro A Ficção do Si Mesmo, a psicanálise de Freud inscreveu uma perda de ilusão de autonomia e autodeterminação do Eu. Por conseguinte, rompe-se não apenas com o binarismo entre indivíduo e sociedade, mas também entre verdade e mentira, ficção e realidade. "No entanto, cabe assinalar que essas construções não são completamente 'livres'. Dependem, como toda relação que se cria no campo humano, de um determinado encontro da história individual com as construções coletivas" (COSTA, 1998, p. 63). A necessidade da ficção como narração de si é uma forma de tornar possível uma relação com o outro, construindo determinações que são inapreensíveis para o indivíduo.

A narrativa de si, de sua própria história, independente da materialidade de seu registro, é essencialmente um ato de fala. Um contar ou recontar que duplica a si próprio como um indivíduo cindido nas posições de sujeito e objeto da mesma ação. "Se a simetria introduz uma condição de dispersão, de problematização no reconhecimento do $e u$, na medida em que este funciona dentro da duplicação que a ficção produz, a própria criação ficcional já é um suposto da possibilidade do reconhecimento da diferença" (COSTA, 1998, p. 73). Narra-se a si e ao outro de forma que suas realidades se registrem como ficções e que a verdade se afirme no próprio ato de criar e compartilhar um enunciado sobre si mesmo.

Todo narrador institui um Eu para historicizar. Por vezes, produz reflexões sobre esse $\mathrm{Eu}$ ao longo da narrativa e, por outras, ele apenas explicita os acontecimentos. Mas, independente do resultado, é necessário reconhecer que há sempre por trás da construção de uma história de vida uma engenharia, um fazer, um conjunto de escolhas. Certamente que somos seres históricos e que nossas narrativas estão permeadas por nossa experiência social, como afirma Elizabeth Tonkin (1992, p. 102): “[...] distinguir o individual do social em qualquer ser humano é como tentar separar os dois lado de um papel [...]". Exatamente nessa direção que nos sentimos alicerçados no olhar sociológico de Norbert Elias para compreender a construção da identidade do Eu nas narrativas de vida.

\section{Duas hISTÓRIAS DE VIDA}

Por meio de duas histórias de vida, nossa busca é entender de que maneira o ato de produzir a narrativa pode ser encarado como um ato de constituição da identidade do $\mathrm{Eu}$ e também como esse ato está permeado pelos discursos sociais que fizeram parte de cada narrador. A história de vida não é um discurso independente do ato na qual ela própria foi construída. O encontro entre o entrevistado e o entrevistador é um ato consciente, demarcado, quase uma encenação teatral na qual é dado ao narrador toda a liberdade para construir, para si próprio e para o outro, uma imagem de si. Seria ingênuo entender que a entrevista revela, para além da vontade do próprio narrador, aspectos inconscientes de sua personalidade. Apesar de isso ocorrer, não é esse o objetivo acordado com o entrevistado nem a expectativa do entrevistador. 
O que se revela em uma história de vida é a construção que o entrevistado faz de si para o entrevistador e para a sociedade (sendo que cada entrevistado tem uma dimensão muito diferente do que significa ter sua história transformada em fonte histórica e em acervo de um museu). A história de vida é a narrativa construída a partir do que cada um guarda seletivamente em sua memória e corresponde ao como organizamos e traduzimos para o outro parte daquilo que vivemos e conhecemos. É nesse ponto que a perspectiva de Norbert Elias se torna uma ferramenta poderosa: ao colocar que cada Eu é também um Nós, Elias dá consistência ao conceito de que cada narrativa de si revela, ao mesmo tempo, a singularidade de cada um e o contexto histórico social. Nelas, estão presentes memórias selecionadas que revelam o que o indivíduo constrói como Eu. Nelas, estão também presentes os fundamentos culturais, emocionais, afetivos, e sociais.

As entrevistas que analisamos foram produzidas em registros audiovisuais e fazem parte do acervo do Museu da Pessoa. Foram realizadas por entrevistadores diferentes, em momentos diferentes (uma foi realizada em 2011 e a outra durante um projeto de coleta de entrevistas no Amapá realizado pelo Museu da Pessoa em 2013). A base metodológica de ambas é a mesma, uma vez que foram produzidas por pesquisadores do Museu da Pessoa que utilizam sua metodologia de trabalho. Nesse sentido, o roteiro de entrevista funciona apenas como uma base de apoio e a procura do entrevistador é aprofundar a história de vida junto ao entrevistado. Nesse contexto, a escuta e a curiosidade do entrevistador norteiam suas intervenções. Apesar da orientação metodológica pedir uma postura "aberta" ao entrevistado, como se verá a seguir, muitas vezes o entrevistador segue suas próprias pressuposições.

O Museu da Pessoa ampliou, ao longo de sua trajetória, as formas de captação de histórias. Atualmente, tanto as histórias escritas enviadas por internautas para o seu portal quanto entrevistas feitas em estúdio e/ou em contexto variados são consideradas parte de seu acervo, uma vez que se entende que o seu acervo é composto por histórias pessoais, sejam elas escritas, contadas em entrevistas, em rodas de histórias ou em outras circunstâncias.

As duas entrevistas duraram cerca de duas horas e contaram com um entrevistador e uma equipe de vídeo. A primeira foi realizada no estúdio do Museu da Pessoa, em 2011, com Auro Lescher, psiquiatra da Universidade Federal de São Paulo (UNIFESP), coordenador do Projeto Quixote e psicoterapeuta. Sua entrevista foi feita a pedido da organização global de empreendedores sociais Ashoka, para avaliar o impacto de um programa de intercâmbio.

A segunda entrevista aconteceu em 2013, no Amapá, em uma comunidade ribeirinha que estava prestes a ser inundada pelas obras de uma hidroelétrica. Sinair Nelson Garcia, mais conhecido como Grande, nasceu em Itumbiara, Goiás em 1954. Seus pais, agricultor e lavadeira, tiveram seis filhos. Ele saiu de casa aos 11 anos de idade, após a morte da mãe e foi trabalhar no garimpo em Tocantins. Ganhou e gastou muito dinheiro trabalhando como garimpeiro em várias regiões do Norte do Brasil. Com os índios aprendeu a fazer remédios a base de plantas medicinais. Atualmente, trabalha colhendo castanhas no município de Laranjal do Jari. A entrevista de Sinair foi realizada na própria comunidade ribeirinha por Rosana Miziara, do Museu da Pessoa. 
Escolhemos essas duas histórias de vida com um propósito. Auro Lescher faz parte de um contexto histórico social tipicamente ocidental. É judeu, de origem europeia, psicanalista e ativista social. Sinair é garimpeiro, castanheiro e garrafeiro. Em sua herança cultural estão presentes traços de culturas europeias, indígenas e africanas. Apesar das grandes diferenças culturais e sociais, nossa hipótese é a de que podemos apreender como o processo de constituição do Eu se apresenta em diferentes narrativas, relatando hábitos e valores que dão sentido à própria vida.

Toda entrevista começa basicamente da mesma maneira: o entrevistador perguntando ao entrevistado nome, data e local de nascimento, nome dos avós, a atividade dos pais etc. Essa introdução, acordada entre entrevistado e entrevistador, serve a um processo de contextualização, assim como a um ritual de aproximação. Serve ainda como forma de explicitar a função do encontro que é a produção de um documento histórico. É como se disséssemos: sim, já nos conhecemos, mas agora estamos entrando em um tempo espaço diferente. Estamos construindo um documento para os outros e sua história é o cerne deste documento. Vamos começar então? A câmera liga, o entrevistador posiciona-se e dá início à encenação. Não há qualquer intenção em disfarçá-la:

Karen - Onde você nasceu, data?

Auro Lescher - Eu nasci em 24 de agosto de 1962, no Bom Retiro em São Paulo.

Karen - Os seus pais eram de lá? Como eles chamavam?

Auro - Eles chamam Raquel Lescher e Isaac Lescher. Eles nasceram aqui no Brasil, em São Paulo, no Bom Retiro. Moraram no Bom Retiro. Eu morei no Bom Retiro até os 13 anos. Os pais dos meus pais vieram da Europa por conta do nazismo.

Karen - Vieram da onde?

Auro - Vieram da Polônia.

Karen - E da sua mãe?

Auro - E da minha mãe também, da mesma região. Então, eu sou um filho de... Meus pais se encontraram muito cedo, ela tinha 16 anos, ele tinha 22 anos, depois de um ano de namoro eles casaram e ela me teve com 17 anos e ele com 23, muito jovens (MUSEU DA PESSOA, 2017).

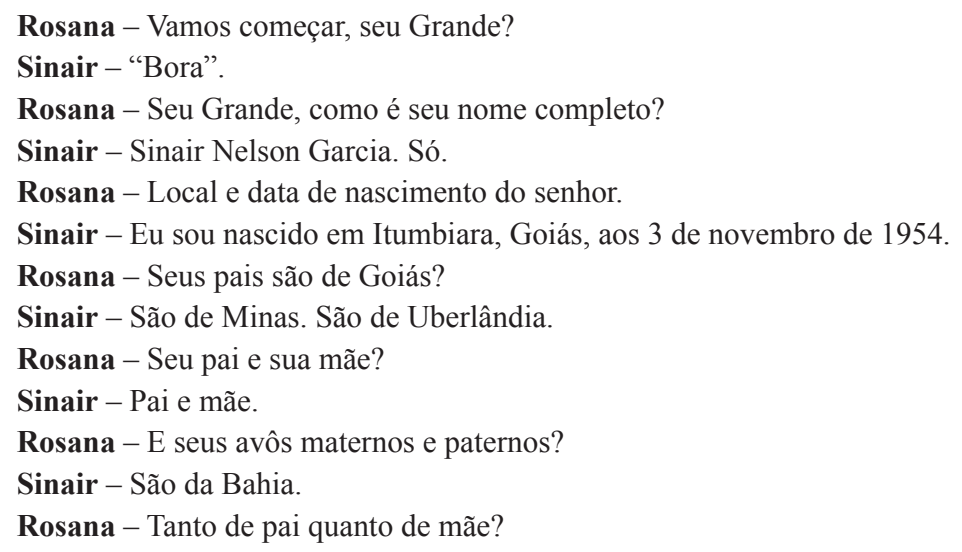


Sinair - Tanto de pai quanto de mãe.

Rosana - Seu pai e sua mãe se conheceram na Bahia?

Sinair - Não. Conheceram em Minas.

Rosana - Por que seus avôs saíram da Bahia e foram para Minas?

Sinair - Não, os meus avôs eu não sei contar bem deles.

Rosana - O que seus avôs faziam? Você sabe?

Sinair - Era tudo agricultor. Um dos avôs era criador, ele tinha criação de gado, essas coisas, porco. É o pai da minha mãe.

Rosana - Que era da Bahia também?

Sinair - Era da Bahia também.

Rosana - E como eles saíram da Bahia e foram parar em Minas Gerais?

Sinair - Ah, é o mesmo negócio de eu sair lá do Goiás e vim parar para cá. Eu acho que foi assim, procurando as melhoras. Aí eu rodei parte do país e vim me agradar aqui (MUSEU DA PESSOA, 2017).

Os dois entrevistados respondem ao estímulo do entrevistador de forma bastante diversa. Auro Lescher possui uma relação de cumplicidade com o entrevistador. Já explicita que os avós vieram por conta do nazismo e assume que já se tenha total consciência do que significa esse fato. Sinair responde sinteticamente. Podemos ver a entrevistadora procurando "gatilhos", até que finalmente ele "explica" tomando a si próprio como exemplo. É quase uma concessão que faz para a entrevistadora. No entanto, sua reação é monossilábica e a entrevista continua dessa forma durante um bom tempo. Já Auro segue sua história e, nas duas perguntas seguintes, já se localiza e seleciona, por conta própria, o que quer explicitar sobre seus pais, sua infância e a constituição de sua identidade Eu.

Auro - Muito, imagina só, minha mãe com 17 anos, meu pai com 23, o primeiro filho, neto, sobrinho de uma família judaica no Bom Retiro, uma grande expectativa, naquela coisa do primeiro menino que nasce com um problema. Quando eu nasço, eu nasço com o pé torto congênito. Meu pé esquerdo, por questões lá durante o processo de gestação, de mobilidade, nasceu torto e aí imagina a frustração de uma menina de 17 anos, um pai de 23, avôs, aquela expectativa que de repente sai defeituoso. E aí, o que fazer com isso? "Opera já, opera aos 15 anos", dependendo dos médicos que eles foram consultando. Felizmente eles gostaram de um médico chamado Bartolomeu Bartolomei que era um ortopedista que tinha um trabalho na Santa Casa, ele tinha consultório e era responsável pelo Pavilhão Fernandinho que era um lugar na Santa Casa de Misericórdia de São Paulo onde ele tratava questões ortopédicas e síndromes de crianças das mais variadas nesse Pavilhão Fernandinho. E o tratamento que ele propôs e que meus pais aceitaram naquele momento ao invés da cirurgia foi a bota de gesso de mês em mês, ir desentortando meu pé torto. E foi super bom esse primeiro ano, eu não tenho mais pé torto, eu ando normalmente, eu não tenho nenhuma limitação, curei a minha deformidade

Karen - E aí, foi neto único por quanto tempo?

Auro - Por dois anos, porque aí veio a minha irmã. Mas esse primeiro ano foi tão importante pros meus pais e pra mim também, porque imagina tem fotos de eu neném no jardim de Santos com a perninha coberta porque era uma coisa constrangedora um neném, tão assim esperado, torto, com gessinho, era uma 
coisa... E eu gordo, parecia um Buda, acho que compensatoriamente eles me davam mais comida, eu era fortinho, assim, gordinho. Mas a minha mãe fez uma promessa e não ia deixar barato, "se o meu filho curar...", a menina de 17 anos fez essa promessa: "Se o meu filho curar dessa perna torta, todo ano na época do aniversário dele, agosto, eu vou fazer uma festa no Pavilhão Fernandinho". Toda a minha infância até o início da minha adolescência era um momento de muita responsabilidade, em agosto ela ia na 25 de Março e comprava um monte de brinquedinho, lapisinhos, docinhos, de gibis e durante a semana anterior da data da festa no Pavilhão Fernandinho a gente botava nos saquinhos e tal, esse ritual eu fui crescendo e vivendo ao longo de muitos anos da minha infância. E eu estou falando tudo isso porque eu acho que todo ano que eu chegava criança, três, quatro, cinco, seis, sete, dez, 12 anos, todo mês de agosto entrar no Pavilhão Fernandinho, que são aqueles prédios antigos, elevador de ferro, eu me lembro o som do ferro fechando o elevador, o elevador subindo, chegando no terceiro andar do Pavilhão Fernandinho, quando se abria, o que é que via lá? Eu entrava numa coisa muito louca, tinha tudo a ver comigo, eu sabia que tinha a ver com uma deformidade curada (risos), uma promessa da minha mãe da qual eu me sentia fazendo parte necessariamente. Demorou até eu perceber que a promessa era da minha mãe (risos) (MUSEU DA PESSOA, 2017).

Podemos entender que, nesse trecho, Auro está conscientemente pontuando os elementos que o marcaram na infância (apesar de grande parte dos eventos serem antes uma "projeção" de sua história). Certamente ele não tem como recuperar o que sua mãe, pai ou avô sentiram quando o viram com o pé deformado, mas todo esse quadro serve já como um elemento para a construção do sentido que ele dará para a sua trajetória.

Sinair segue seu relato de forma sintética e, após inúmeras tentativas da entrevistadora, explica a origem de seu nome:

Rosana - Você sabe por que você tem esse nome: Sinair?

Sinair - Não, isso foi minha mãe que tirou esse nome, não sei de onde. E aí não me registrou logo, e quando eu fui registrar já foi por minha conta própria, mas meu pai me contou que ela queria esse nome, aí eu coloquei. E aí esse nome até que deu certo, porque quando eu fui lá para aldeia que eu falei, os nomes lá quase tudo combinavam com o meu. O meu era Sinair, lá tinha Sitirê, Uincarnê, Zemicê, Antoniê, era tudo assim, aí deu certo lá com o meu também (MUSEU DA PESSOA, 2017).

Enquanto Auro assinala, em sua história, o peso do empenho da mãe e suas promessas (e ri disso), Sinair mostra como ele próprio teve que registrar seu nome. Esse tom se repete inúmeras vezes em suas narrativas e podemos dizer que é um traço constitutivo de seu Eu. Toda sua narrativa é marcada por esse distanciamento afetivo com qualquer elemento familiar e pela construção de uma vida totalmente alheia ao contexto de origem:

Rosana - E tinha festa assim que você comemorava na sua casa?

Sinair - Na minha casa...

Rosana - Natal, aniversário. 
Sinair - Ah, Natal tinha. Mas também era só Natal mesmo.

Rosana - Como eram os Natais?

Sinair - Ah, o Natal a minha mãe prevenia bem antes, ajeitava aqueles frangos no terreiro, tudo é para o Natal, tudo, tudo. Às vezes uma porcazinha para comer assada no Natal. Aí arrumava um vinho, mas o vinho era só para os adultos. Eu acho que a gente nem falava em negócio de Fanta, Coca, era só guaraná. Aí arrumava um guaraná lá para os pequenos, aí ia comemorar o Natal. Outro dia que comemorava de novo era o Sábado de Aleluia. Que durante a quaresma ela não batia em ninguém, nem ela e nem ele, mas parece que botava tudinho num caderno, para deixar tudo para o Sábado de Aleluia. Portanto que eu nunca amanheci Sábado de Aleluia em casa, que eles pegavam era na cama, antes de levantar. Aí eu nunca amanheci um Sábado de Aleluia em casa. Na quaresma a gente podia fazer, eles só falavam ali, reclamavam, mas não batiam, não, que era pecado. Agora, Sábado de Aleluia. Aí: "Você está apanhando sabe por quê? Por causa daquele dia que você fez isso, isso e isso". Acabava aquele dali: "Agora você vai apanhar de novo sabe por quê? Porque tu fez tal dia isso, isso e isso".

Rosana - Seu pai?

Sinair - Era. E aí... Que nem eu, que não parava, ia dar quase o dia todo apanhando.

Rosana - Você não parava?

Sinair - Aí eu não dormia logo de sexta-feira em casa (MUSEU DA PESSOA, 2017).

Sinair não explica a relação com os pais e tampouco explicita sua reação, mas é certo que constrói um Eu que reage à atitude dos pais. Não faz, como Auro, uma avaliação da situação, mas pontua que dorme fora para não apanhar (ao mesmo tempo em que reconhece que mereceria por "não parar"). Nessa fala, podemos encontrar certos valores sociais implícitos, tais como autonomia, valentia e dureza. Sem avaliar o impacto desse contexto em si, Sinair escolhe, ao longo de toda entrevista, falas que demonstram seu desapego e sua capacidade de se virar. Auro, por sua vez, narra sua história de forma a que ela faça total sentido ao que ele assume como sendo característico de seu Eu (chega, inclusive a assinalar para a entrevistadora, quando vai amarrar o sentido de sua fala, quando diz: eu já vou chegar aí...).

Karen - 70 anos de psicanálise (risos).

Auro - Eu vou chegar aí... Não era minha a promessa, mas enquanto eu não percebi isso, eu fui indo, e abria aquilo no terceiro andar e eu via o quê? Crianças deformadas, uma cena assim, Pavilhão Fernandinho: crânios enormes, pés puxados pra cima, coisas assim, síndromes das mais variadas e pessoas muito pobres porque era um trabalho social também do Bartolomeu Bartolomei lá na Santa Casa como professor titular de ortopedia e tal. Eu fui todo ano exposto por aquele ambiente felliniano muito do deformado, do estranho, do diferente, eu próprio tendo em mim desde o nascimento uma marca. Depois eu fiquei pensando, ser judeu já é uma marca a priori de alguma diferença, porque os outros olham pra você e lembram que você é judeu. Felizmente, eu acho que essa marca registrada, o jeito dos meus pais lidarem com isso, e muito por causa 
da escola, do Scholem que foi muito importante, que eu me senti muito confortável como judeu brasileiro, brasileiro judeu ou um ser humano. Eu me lembro de um dia que eu fui aos 16 anos pra Israel fazer aquelas clássicas viagens com objetivos sionistas, eles juntavam grupos de jovens e eu fui aos 16 anos e em uma das atividades lá na escola agrícola em que a gente estava pra colher laranja durante dois meses, o Rabino fez uma experiência com a gente, botou cartazes nas paredes: 'Eu sou brasileiro', 'Eu sou judeu', 'Eu sou ser humano', 'Eu sou sionista', fez lá uma dinâmica e pediu pra cada um ir junto do cartaz que ele se identificasse mais, $90 \%$ do grupo foi pro 'Eu sou judeu', o que ele gostou. Uma menina foi pro 'Eu sou sionista' e ele adorou. Eu e o Beni, meu amigo do Scholem, fomos os únicos dois que foram pro 'Eu sou ser humano'. Eu acho que o Scholem deu muito, por valorizar a arte, a cultura e você é judeu, mas você é brasileiro, você é brasileiro, mas é judeu, pouco importa, isso é normal. Isso foi muito importante pra eu sentir, com essa marca desde nascer, o ser diferente, mas não ser diferente. Eu sou muito confortável com essa diferença, ser judeu. E depois, torto que desentortou, com o pé torto congênito exposto por essas repetidas anuais experiências fellinianas, eu fui tendo um diálogo desde o começo, coisas que eu estou pensando alto até aqui agora assim, muito desde o começo exposto ao diferente, ao bizarro, ao estranho e com desejo de me aproximar por me sentir talvez um pouco assim também. Bom, aos 11 anos eu começo a minha psicoterapia (MUSEU DA PESSOA, 2017).

Na narrativa de Auro, podemos perceber o exercício contínuo de alinhavar como a escola, a infância, a herança judaica fazem parte de sua identidade, inclusive com momentos de reconstrução de sua história quando ele diz "coisas que eu estou pensando alto até aqui agora assim". É um exercício contínuo de autorreflexão no qual o narrador vai se construindo com marcas que ele tem como suas, mas que, ao mesmo tempo, são marcas do coletivo: judeu, brasileiro, diferente... ao longo de sua narrativa ele incorpora tais traços como seus e constrói sua individualidade. Vamos agora observar quais as estratégias de Sinair quando conta por que e como saiu de casa:

Rosana - O que você aprontava?

Sinair - Ah, eu gostava muito de atentar com os outros irmãos. Portanto que quando minha mãe morreu, os outros tudo ficaram em casa, eu resolvi sair, que eu vi que não ia ter mais nada para mim lá. Os irmãos não se davam muito comigo, que eu bagunçava muito com eles.

Rosana - Bagunçava como?

Sinair - Às vezes meu pai liberava para um ir passear, não liberava para mim: "Não, você não vai, só vai o fulano, o fulano e o fulano".

Rosana - Por que ele não liberava?

Sinair - Não, os outros que reclamavam para ele: "Não, ele não pode ir, porque chega lá, ele vai atentar lá, fazer vergonha a gente lá e tal". "É. Tu não vai." Os outros se arrumavam tudo, calçavam, na hora que eles iam sair, eu passava bosta de galinha na roupa deles e bagunçava com eles. Era assim. E já corria também para o mato. Quando minha mãe morreu, eu digo: "Agora acabou o mundo para mim, eu vou ter que achar outro lugar". 
Rosana - Mudou muito sua vida depois que ela morreu?

Sinair - Foi. Mas mudou muito.

Rosana - Ela morreu do quê?

Sinair - Morreu de parto também. Ela passou sete anos sem ter filho, aí engravidou e foi para dita Itumbiara de novo, na mesma Itumbiara ela morreu. Ela ficou com dor lá no mato três dias e a parteira tentando, tentando, e com três dias a parteira despachou. Aí ela foi para o médico, chegou lá passado da hora, aí morreram ela e a criança.

Rosana - E você quando era pequeno você ia muito... De quanto em quanto tempo você ia para Itumbiara.

Sinair - Não, pouco ia eu mesmo, não tem... Eu me lembro de ir a Itumbiara quando eu já tinha 12 anos, por aí assim, eu já ia, mas era jogar bola, essas coisas assim.

Rosana - Aí quando o senhor fez 11 anos...

Sinair - Foi. Foi com 11 anos...

Rosana - Sua mãe morreu. O que mudou na sua vida?

Sinair - Mudou que aí eu saí.

Rosana-Com 11 anos?

Sinair - Foi. Foi com 11 anos que eu saí de casa.

Rosana - Você decidiu ir para onde?

Sinair - Decidi ir para o norte de Goiás, que hoje é Tocantins.

Rosana - Mas por que para Tocantins?

Sinair - Não, já vim no intuito de garimpo já, de garimpo de cristal que tinha nessa época.

Rosana- Mas como você sabia do garimpo com 11 anos?

Sinair - Não, tinha gente que trabalhava por aí, e ia para lá para o estado de Minas, aí contava, e eu ficava escutando aquelas conversas.

Rosana - Quem contava? Assim, qual foi uma pessoa que te aconselhou?

Sinair - Nós mesmos tínhamos um vizinho lá, o senhor Zezinho, ele trabalhava nesses garimpos por aí, garimpo de cristal, aí ele contava. Aí eu saí à procura de garimpo.

Rosana - Ele trabalhava? E o que ele contava?

Sinair - Contava que ele ganhava muito dinheiro. E ele ganhava mesmo. Aí eu vim.

Rosana - Mas você sabia o que era garimpo?

Sinair - Não, sabia, mas não pensava que era do jeito que é. Sabia que era atrás de minério, essas coisas, só que não é bem assim. É atrás de minério, mas não é só chegando e achando minério.

Rosana - Você chegou com 11 anos. Como você veio? Com que dinheiro? Como você chegou?

Sinair - Nesse tempo não tinha essa fiscalização toda que tem hoje em dia para de menor.

Rosana - Mas você chegou como?

Sinair - Estava desbravando a Belém-Brasília. Conhece bem a Belém-Brasília? É uma rodovia principal de Brasília para Belém. Aí estava na abertura dela ainda, no desmatamento dela, aí eu vim. A gente passava era de mês para chegar aí a essas regiões. 
Rosana - Mas vinha como? De ônibus?

Sinair - Era de ônibus e aquelas caminhonetas que faziam corrida.

Rosana - Como o senhor conseguiu dinheiro para passagem?

Sinair - Não, eu não vim só de uma vez. Eu vinha, a hora que acabava, eu parava, trabalhava naquelas fazendas por ali, ganhava de novo, tornava ir mais um pouco. Eu passei uns seis meses para chegar lá (MUSEU DA PESSOA, 2017).

O que chama atenção nesse trecho de Sinair é como ele se posiciona de diferentes formas frente a si próprio. Hora ele se coloca no momento da entrevista ("eu sabia", "eu corria"), hora ele se coloca em outra perspectiva, já em outro espaço-tempo, quando, por exemplo diz "vir" ao invés de "ir". Apesar de não exercitar o mesmo tipo de reflexão de Auro, Sinair faz o mesmo movimento de se ver a si mesmo como o objeto que está sendo narrado. $\mathrm{O}$ fato de constituir um Eu como o objeto central da narrativa é parte dessa gramática. Às vezes, o entrevistado se coloca no centro das ações e, por meio do que vem a conectar, estabelece as ações de seu Eu. Esse exercício revela, de certa forma, a alteridade do narrador com seu Eu narrado. O Supereu tem um papel importante nesse processo na medida em que permeia as escolhas do narrador, assim como orienta o sentido à sua vida. Na narrativa de Auro, cada evento tem um papel a cumprir na tessitura do sentido de sua vida.

Auro - Essa coisa do demasiado humano, a medicina me trouxe muito e, claro, Escola Paulista de Medicina, uma universidade pública que trata de gente pobre e como também já estava dentro de mim esse contato com gente pobre, diferente e sofrida desde lá do Pavilhão Fernandinho. Tudo aquilo pra mim era muito presente, forte, e a psiquiatria e a medicina foram me dando tantos instrumentos e aplicativos para uma interação, eu gosto tanto de gente, de histórias, como vocês fazem aqui também... Mas cada vez eu estou sendo tão mais seletivo (risos), aparentemente é contraditório, mas acho que não é. Acho que conforme a gente vai ficando mais velho, a gente vai ficando mais, não sei, acho que a energia você vai tendo que gastar de uma forma mais focada, assim, você vai sendo mais, e eu nunca fui muito expansivo, muito pelo contrário eu sempre fui muito... Então, eu gosto muito de gente, mas gente boa (risos). E eu fui desenvolvendo, assim, eu não quero estar junto de gente que não seja boa, então, meu trabalho social juntando tudo isso foi sendo meio natural, eu fui virando médico, psiquiatra, droga, a questão da droga como algo na psiquiatria que me fascinava, a intensidade das pessoas que lá pelas tantas se perdem nessa questão que é muito interessante, são essas coisas que a gente bota pra dentro do corpo pra alterar a percepção sobre a gente mesmo e sobre o mundo que a gente toma, injeta, cheira, fuma e que faz e sempre fará. A humanidade sempre terá essa possibilidade, essa necessidade de perceber-se de uma forma diferente, ter outra consciência e que se não é quimicamente, é existencialmente, a gente não tem outro jeito, não tem 'inventar outra história' mesmo, que mundo é esse hoje? Então essa coisa de saber que outra história é possível sempre, desde o meu desentortamento do meu pé, poder depois ver que aquela coisa da minha mãe, não era minha coisa, e poder me libertar depois um pouco e a terapia, a ludo-terapia, até agora eu faço terapia, graças a Deus que eu faço terapia (risos), hoje eu vou quinzenalmente ao meu terapeuta apertar os parafusos, esse sau- 
dável movimento de você dar um passo atrás e olhar pra sua própria vida, formular certas hipóteses, nunca desvendar um enigma, eu não acredito nisso, "ah, foi por causa do meu pé torto, congênito que eu virei empreendedor social", besteira, acho que é um sopão que vai cozinhando ao longo de tantos, muitas das coisas você até formula certos sentidos e hipóteses, muitas outras você nem imagina, vai imaginar lá na frente, aos 70 anos, sei lá... E essa coisa de sou diferente, mas não sou diferente, a diferença que não é diferença que compõe tudo isso, eu acho que é a coisa mais importante. E ai virei empreendedor social, a Ashoka (MUSEU DA PESSOA, 2017).

Auro vai amarrando toda sua trajetória de forma que faça sentido, que é o de tornar-se empreendedor social, criar um trabalho social, usar a medicina. A construção dessa narrativa de si é feita dentro de determinado contexto, de modo que ela destaca certos traços de sua identidade que são compartilhados com a entrevistadora e que estão de acordo com o objetivo da entrevista. Nesse sentido, podemos afirmar que a identidade do Eu se constrói na singularidade da relação que o indivíduo estabelece com o outro. Mas, como Auro mesmo diz, "o sopão" dos eventos pontuados por ele alinhavam-se em um sentido que, apesar de pessoal, possui os traços do contexto sociocultural ao qual pertence. A história de Sinair é muito menos avaliativa. O sentido dos acontecimentos estão menos amarrados e, podemos dizer, que são, de certa forma surpreendentes para a cultura tipicamente ocidental judaico cristã.

Rosana - O senhor se lembra do primeiro ouro que o senhor achou, a primeira vez?

Sinair - Eu lembro.

Rosana - Como foi?

Sinair - Não, o primeiro dia eu não peguei parceiro, eu estava sozinho.

Rosana - Como foi.

Sinair - Só tinha um dentro da grota, ele que me falou que tinha ouro, aí eu fui para lá. Ele falou: "Agora, se tu quiser, tu tira aí esse barranco aí, eu acho que ele vai dar um ouro" "Será?" “É”. Eu falei: “E esse seu aí?". Ele já tinha tirado um. Ele disse: "Esse meu aí deu 300 gramas". Só que era assim, olha, dessa fundura assim. Eu digo: "Rapaz, isso é que é. Jogar toneladas e toneladas de barro para cima para tirar grama de ouro é muito pouco". Ele disse: "É pouco, mas só que o valor é muito". Eu fui e tirei esse primeiro barranco. Quando eu queria errar, ele me ensinava: "Não, não faça assim. Faça assim e assim". Aí eu fui fazendo do jeito que ele mandava. Agora, para lavar não tem como só um lavar, tem que ser dois.

Rosana - Como você achou?

Sinair - A gente só acha quando lava a terra. A gente lava tudinho, a terra sai e o ouro fica. O ouro é um produto mais pesado que tem na terra, então a gente bota uma velocidade de água para gente lavar. Aí a areia vai saindo, pedra, mas o ouro não sai. A gente forra aonde vai passar o ouro com aquela sarrapilha. Ela não tem um pelo? Aí o ouro entranha tudinho naquela farrapilha, não vai dali para frente. O meu deu 400 gramas. Ele falou: "Olha...".

Rosana - O primeiro?

Sinair - O primeiro. 
Rosana - E aí é só seu ou você divide com quem lavou?

Sinair - Não, não tinha para quem dividir, era meu, ele me deu.

Rosana - E aí?

Sinair - Eu falei: "Bom, agora eu vou à cidade, vou vender esse ouro e vou ver o que sobra para mim".

Rosana - Você vendia para quem?

Sinair - Tem os compradores. Até hoje tem comprador de ouro para todo canto.

Rosana - E aí?

Sinair - Porque a mercadoria que eu comi enquanto eu estava tirando lá esse barranco eu comprei fiado. Eu fui lá vender o ouro, vendi, paguei lá e sobrou muito dinheiro ainda. Eu comprei outras mercadorias e aí estourei o resto.

Rosana - Estourou como?

Sinair - Gastei tudinho.

Rosana-Como?

Sinair - Na "putada". Acabou tudo. Aí eu voltei para lá de novo.

Rosana - Como "putada"? O que é "putada"?

Sinair - São as quengas. Hoje o povo só fala as piriguetes. Aí eu fui lá até quando acabou tudo.

Rosana - Gastou tudo com as quengas?

Sinair - Foi. Aí ficou assim. Viciei nisso: ia lá ao garimpo, ganhar o dinheiro, e vim e estourar tudo.

Rosana - O senhor bebia?

Sinair - Bebia..

Rosana - Seu Grande, aí o senhor gastava o dinheiro e não juntava.

Sinair - E não juntava.

Rosana - E seu objetivo era o quê? Era ficar lá vivendo desse jeito?

Sinair - É. Achei boa a vida.

Rosana - E o senhor bebia muito?

Sinair - Não. Nessa época, não. Depois que foi aumentando, aumentando.

Rosana - O senhor gastava o dinheiro por quê? Por que tinha que pagar as mulheres?

Sinair - É. Tinha que pagar e mesmo eu ficava lá até acabar mesmo. Não dava para gastar tudo hoje, eu tinha que ficar amanhã para eu acabar de gastar para eu poder ir embora. Eu era assim. Eu acho que eu não podia levar nada para trás, sabe? Era assim que era. Tinha que gastar (MUSEU DA PESSOA, 2017).

Podemos perceber, ao longo dessa narrativa, duas questões marcantes: o conflito cultural entre a entrevistadora e o entrevistado e a lógica do entrevistado que termina por explicitar o sentido que dá a suas ações quando diz: Eu acho que eu não podia levar nada para trás, sabe? Era assim que era. Tinha que gastar. Ainda que descreva suas ações sem procurar justificá-las, o narrador tem plena consciência para quem está falando. Percebe o sentido das ações e observamos claramente a presença do seus valores morais quando narra a história de por que deixou o garimpo:

Sinair - Aqui eu trabalhei nesses garimpos aí para cima, quase todos eles. O dia que eu assisti um homem matando o outro para roubar dez gramas de ouro, aí nesse dia eu desacorçoei com o garimpo daí. 


\begin{abstract}
Rosana - Onde foi isso?
Sinair - Foi no garimpo do Flexal. O homem com dez gramas de ouro...

Rosana - Em Laranjal?

Sinair - Não. Garimpo do Flexal, aí para cima. Eles tiraram o barranco, o que tocou para esse senhor foi dez gramas. Ele disse: "Eu vou lá para pista mandar esse ouro para minha mulher em Santarém”. Aí pegou o ouro, botou no bolso, a hora que ele andou um pouco, o outro estava escondido já o esperando, matou, foi e pegou o ouro. Ah, aquilo me desgostou muito. Que eu vi muita morte lá, mas não assim para roubar dez gramas de ouro só. Já vi um matando para roubar um quilo, meio quilo, 300 gramas.

Rosana - Você viu matando?

Sinair - Mas dez gramas? Eu digo: “Ah, não dá mais garimpo. Eu vou...” (MUSEU DA PESSOA, 2017).
\end{abstract}

As narrativas orais apresentam diferentes estratégias do narrador (LABOV, WALETZKI, 1967). Uma delas é a avaliação. É uma estratégia para o narrador posicionar-se frente a si próprio e ao ouvinte. É essa a estratégia de Sinair para justificar o motivo da mudança em sua trajetória de vida. Poderíamos dizer que é também uma presença da construção de seu Eu que postula quais os limites morais para a sua vida.

É interessante como Auro vai juntando seus aprendizados e seu sentido de vida que o leva a fundar o Projeto Quixote. Durante a narrativa ele vai se dando conta de quanto as coisas que vivenciou quando criança (ou que pontuou na narrativa) tiveram influência sobre o trabalho que acabou criando. Sinair não é tão explícito e o que utiliza para se "definir" inclui elementos culturais muito diferentes. Para Auro, sua missão vem de sua "história", para Sinair, do mundo espiritual. Ambos, no entanto, se veem como portadores dessa missão e, quando narram, se encontram nesse seu Eu. Nos dois trechos a seguir, Auro e Sinair relatam a forma como apreenderam e exercitaram suas "missões" de vida. A diferença dos contextos é surpreendente, como observamos a seguir:

Auro - O fato é que não tinha dinheiro, era só eu iniciando essa coisa e ao mesmo tempo a minha vida aqui de universidade, de consultório, de Escola Paulista de Medicina. Lá pelas tantas, como aqui eu fui trabalhando mais a dimensão clínica da droga, junto tinha essa coisa de especialista em droga, razoavelmente já conhecido, reconhecido aquilo que eu falava no metiê clínico nesse campo da farmacodependencia, me indignando muito junto com outras já pessoas desse mesmo ambulatório da Escola Paulista de Medicina com a questão da criança e do jovem em situação de rua que usa droga. Vamos fazer uma coisa que a gente não sabe bem como faz, mas a gente tem ao nosso favor: primeiro, a indignação de que isso não é normal, criança usar crack, Cracolândia, vamos parar tudo, começar de novo que não está certo, nós que somos especialistas nesse negócio, vamos tentar ajudar isso ai? O reitor gostou de mim, já me conhecia de outros carnavais, alugou uma casinha, eu comecei a juntar dois, três, quatro colegas desse ambulatório da Escola Paulista de Medicina, "vamos fazer um negócio assim, o reitor está a fim de alugar uma casinha pra gente, vamos?” A gente já conhecia uma pessoa que nos colocou em contato com o Governo Covas, na época a secretária do Covas, dona Marta Godinho, uma pessoa muito sensível, 
apostou no Quixote, foi juntando as coisas, tivemos um convêniozinho e aí começou o Quixote: "E vamos chamar Quixote porque a gente é romântico, quer mudar o mundo, então, já vamos chamar de Quixote". Não demorou um mês pra gente ver que essa coisa da droga nessas crianças não tinha nada a ver com o que a gente estudava nos livros e via nas clínicas, nos ambulatórios e nos consultórios, porque a questão da droga entre crianças de rua era uma questão muito diferente clinicamente, exigia uma outra abordagem, como que droga em criança de oito anos e qual é a abordagem? Bom, vamos oferecer, artificialmente, intensamente vivências infantis, de criança, de brincadeira, de estético, de ético, de oficinas, de coisas básicas hoje, que há 20 anos atrás os meus colegas clínicos olhavam pro Auro como um excêntrico, um bizarro assim, mas ele é tão legal deixa ele fazendo um grupinho de teatro com os drogados lá no teatro, era o poeta meio viajandão (MUSEU DA PESSOA, 2017).

Sinair - Os remédios. A maioria foi lá. E aí eles me ensinaram também para gente ter experiência com remédio, tinha que ter experiência com os animais.

Rosana-Quem?

Sinair - Com os animais do mato. Por exemplo, essa macaca que estava aqui eu ainda não vi ainda, mas esse vermelhão, maior do que essa que tem aí, a gente atira nela, às vezes ela não morre, aí ela corre e pega um galho, umas folhas de mato, esfrega assim, ela passa onde a gente atirou, no ferimento, aí ela fica boa, ela não morre. Mas daí o povo falava isso, aí eu comecei a ver isso, ela fazer isso mesmo. A gente atira, aí quando ela está ferida, ela corre, chega lá, apanha umas folhas, esfrega assim e passa. Eu fui ver, não é toda folha que ela pega, tem uma folha. Então nessas folhas delas foi que eu descobri que aquilo é bom mesmo para qualquer ferimento. Não é toda folha que ela pega. Então é um pau milagroso que só. Por exemplo, uma pessoa que está baleado também, um cristão, a gente pode fazer a mesma coisa, que faz o efeito. Outra coisa, o jacuraru, você conhece? O jacuraru, ele briga com a cobra, briga, briga, briga, briga, a hora que a cobra o acerta, tcham, aí ele corre. Ele vai lá, cava assim rapidinho lá numa batata, vai e come a batata, aí volta de novo, aí ele briga até matar a cobra. Então eu já assisti isso. Depois eu fui e arranquei a batata dele, e levei. Não foram oito dias, passou um rapaz lá que ia muito mal, que a cobra o mordeu, eu digo: "Ah, eu tenho um remédio aqui muito especial”. Eu peguei, tirei umas lapinhas da batata, pisei, botei dentro de um copo com água, mexi, mexi, tem que dá para ele beber. Deu para ele beber, daí um pouco ele estava bom. Digo: "Rapaz, isso aí é bom mesmo, o remédio do jacuraru".

Rosana - E o senhor aprendeu observando junto com os índios?

Sinair - Foi. Foi.

Rosana - Que mais o senhor aprendeu?

Sinair - Os índios me mandavam observar essas coisas assim.

Rosana-Mas esse lado espiritual assim, de perceber a pessoa? Não foi com eles?

Sinair - Não, isso daí não. Isso daí eu acho que já vem de família, com meu avô.

Rosana - O senhor já tinha isso antes?

Sinair - Já. Mas só que eu não me importava com isso.

Rosana - Mas quando o senhor começou a ter sinais de que o senhor tem essa espiritualidade?

Sinair - Foi quando eu passei de 35 anos. 
Rosana - O que aconteceu que o senhor notou?

Sinair - Aconteceu que certa mulher estava doida, que ninguém podia segurá-la, que ela derrubava todo mundo, e a mãe dela muito chorando, aí ela foi passando correndo perto de mim, eu peguei no braço dela. E ela dava cada pulo. E eu consegui segurar sozinho, coisa que seis homens não estavam dando conta. Eu peguei, segurei, e ela: "Me larga, me larga, me solta". E dava arranco, mas não soltei. E a mãe dela: "Não solta. Não solta". Aí que eu descobri. Digo: "Rapaz...". E outros lá também diziam: "Rapaz, tu não é só". Depois foi um negócio que uma mulher botou numa bebida e trouxe para mim. A hora que eu peguei no copo, o copo partiu na minha mão. Era porque tinha o "coisa" dentro. Aí já foi outro sinal de novo. Eu vim descobrir o resto aqui já no Iratapuru. Foi aqui.

Rosana - E como começou essa história de garrafada?

Sinair - Essa história de garrafada foi assim: tem uma mulher que tem uma pousada ali em Laranjal do Jari, uma das pousadas mais antigas que tem. Então ela adoeceu, aí foi para Belém, lá o médico falou que não tinha mais condição para ela. Aí ela veio embora para o Laranjal. Eu não a conhecia. Um outro que a conhecia que me falou, falou: "Rapaz, eu tenho uma amiga, gente boa demais, estava doente lá para Belém, aí chegou, o médico disse que o câncer dela não tem mais jeito, vai morrer". Eu digo: "O câncer dela é aonde?". Ele disse: "É na costela". Aí eu me lembrei do açacú. Eu digo: "Rapaz, talvez se fizesse uma garrafada para ela, ela melhorava". Ele disse: "Se o senhor quiser fazer, eu falo lá para ela".

Rosana - Você já tinha feito garrafada?

Sinair - Não. Nunca tinha feito.

Rosana - Da onde sai o termo "garrafada"?

Sinair - Pois é. Ele foi, falou para ela, ela mandou que eu fizesse. Aí eu botei o leite do açacú. Digo: "É uma bebida braba que tem dentro". Só que eu botei bem fraquinho, com medo de ela beber e morrer logo. Botei bem fraquinho. Aí ela bebeu, ela sentiu melhor, me mandou fazer outra, aí eu fiz três. Acabou o câncer dela. Aí foi o mesmo que uma música que faz sucesso, sabe? Daí aparecia tanta gente atrás de garrafada.

Rosana - Mas da onde que saiu a expressão "garrafada"?

Sinair - Isso é muito velho isso. Muito antigo. Vou até te contar aqui de uma garrafada aqui, que quando eu era menino ainda já falavam em garrafada. Saiu uma coceira no meu corpo, eu era menino ainda, aí coçava tudo, que estava saindo sangue. O povo disse: "Lá em tal lugar, o médico vai lá uma vez por mês lá no posto, posto de saúde. E ele vai lá essa semana. Por que você não vai lá, rapaz? Vai lá. Leva lá para ele ver, te passa um remédio bom”. Aí eu fui. Quando cheguei lá, o médico disse: "Tira a camisa aí". Eu tirei, ele olhou tudo, disse: "Escuta, lá para o interior que você mora não tem quem faça garrafada?". Eu digo: "Tem". Ele disse: "Pois você volta e manda fazer uma garrafada para ti e outra para mim, que eu estou é ruim também desse negócio". Digo: "Ih, coitado do médico". E ele ficou bom mesmo também, de garrafada.

Rosana - Quantos anos você tinha?

Sinair - Eu tinha uns oito anos, nove anos, por aí.

Rosana - Mas a sua mãe acreditava nisso? Seu pai? Como era?

Sinair - Ah, eles me mandaram ir para o médico. Aí eu fui. O médico falou para 
eu voltar lá e mandar fazer uma garrafada para mim e outra para ele, que ele estava era ruim também daquele negócio. Dei só viagem perdida lá no médico.

Rosana - E quem arrumou a garrafada para você?

Sinair - Foi um parente mesmo do meu pai, da minha mãe.

Rosana - Mas já era costume essa coisa de garrafada?

Sinair - Era.

Rosana - E você pensou que algum dia você fosse virar...

Sinair - Não.

Rosana - Foi por causa dessa mulher com câncer?

Sinair - Foi. E outra também, nem eu gosto muito disso, sabe? Eu queria ter outra coisa, menos negócio de garrafada.

Rosana - Por quê?

Sinair - Muitas vezes já veio gente aí, aí traz o doente para aí, aí: "Não, eu sei que o senhor vai fazer o remédio, tal". E esses doentes que têm essas doenças perigosas atacam mais é à noite. E muitas vezes já passei noite sem dormir ali com doente. Sabe, naquele "gemor". E eu não consigo dormir tendo um gemendo dentro da casa: "Aaaaai. Aaaaai”. Não consigo, não. (risos) Eu tenho que levantar, sair, ir para o mato, vou caçar, só venho de manhã de novo (MUSEU DA PESSOA, 2017).

A narrativa dos dois é muito diferente, mas ambas trazem a construção de um sentido que o entrevistado adota como sendo parte de sua missão de vida e/ou traço pessoal. As diferenças entre a produção das duas histórias (que inclui as diferenças culturais e sociais entre os dois entrevistados) são uma oportunidade para acessarmos como os processos pessoais mostram contextos sociais e culturais diversos ainda que revelem as mesmas humanidades. Além do exercício de constituir um Eu para o outro, o ato de construir uma história de vida possibilita que registros de memória inconsciente do indivíduo tornem-se parte da consciência, ampliando assim o que o entrevistado pode incorporar como parte do Eu. A construção do Eu comporta essas duas dimensões, inconsciente e consciente, e podemos verificar que, muitas vezes, esse ato ocorre durante o processo de construção de uma narrativa de vida pois, segundo Freud (2011b), só pode se tornar consciente o que foi representado/registrado na memória.

Quando esse processo ocorre, pode-se dizer que a entrevista adquire um sentido mais profundo para o entrevistado. O processo de "narrar" a própria história impacta o indivíduo na medida em que o leva a criar e/ou rever o sentido de suas experiências. No livro Em Busca do Sentido, Victor Frankl afirma que não é o que vivemos o que determina o modo como vamos experienciar nosso presente e nosso futuro, mas é o sentido dado ao que vivemos o que importa. Exemplifica, por meio de sua própria experiência de vida, que é a nossa demanda por dar sentido o que nos torna humanos. Em suas próprias palavras: "Ouso dizer que nada no mundo contribui tão efetivamente para a sobrevivência, mesmo nas piores condições, como saber que a vida da gente tem um sentido" (FRANKL, 2011, p. 129). 


\section{CONSIDERAÇões FINAIS}

Quando conectamos conceitos de narrativas, memórias e história estamos, de fato, falando sobre a "criação de sentidos". A construção de uma história de vida é um processo reflexivo e organizativo. Algo que, de determinada maneira, beira o processo terapêutico, mas que, se realizado com o simples intuito de preservação e socialização de histórias, termina por evidenciar o papel do narrador como ator e autor de sua trajetória. Nossas histórias de vida traduzem, de forma bastante singular, o sentido que damos à nossa vida. O sentido é também um modo interessante de perceber os traços sociais incorporados pelo indivíduo.

Existirá uma história de vida sem sentido ou um ser humano que não passe sua vida a traçar e retraçar o sentido para a sua vida? Cremos que não. Apenas as estratégias são diferentes, assim como os recursos socioculturais. Narrar e dar sentido a própria vida é certamente uma dessas características.

\section{REFERÊNCIAS}

COSTA, Ana. A Ficção do Si Mesmo. São Paulo: Companhia de Freud, 1998.

DE CERTEAU, Michel. A Escrita da História, 3. ed. Rio de Janeiro: Forense, 2015.

ELIAS, Norbert. O Processo civilizador: formação do Estado e Civilização. Rio de Janeiro: Jorge Zahar, 1993.

. A Sociedade dos Indivíduos. In: N. Elias. A Sociedade dos Indivíduos. Rio de Janeiro: Jorge Zahar, 1994a.

. Mudanças na Balança Eu-Nós. In: N. Elias. A Sociedade dos Indivíduos. Rio de Janeiro: Jorge Zahar, $1994 b$.

. Mozart: a sociologia de um gênio. Rio de Janeiro: Jorge Zahar, 1994c.

. A sociedade de corte. Rio de Janeiro: Jorge Zahar, 1996.

FRANKL, Victor. Em busca de Sentido. Rio de Janeiro: Sinodal/Editora Vozes, 2011.

FREUD, Sigmund. O Mal-estar na Cultura. Porto Alegre: L\&PM, 2010.

. Psicologia das massas e análise do eu. In: S. Freud. Psicologia das massas e análise do eu e outros textos (1920-1923). São Paulo: Companhia das Letras, 2011a.

. O Eu e o Id. In: S. Freud. O Eu e o Id, Autobiografia e outros textos (19231925). São Paulo: Companhia das Letras, 2011 b.

LABOV, William; WALETWKI, Joshua. Narrative Analysis: oral versions of personal experience. In: Helm, J. (org.). Essays on the Verbal and Visual Arts. Seattle: University of Washington Press, 1967. 
MENNELL, Stephen. Norbert Elias: an introduction. Dublin: University College of Dublin, 1998.

MUSEU DA PESSOA. Disponível em: <http://www.museudapessoa.net> Acesso em: 2 de novembro de 2017.

PORTELLI, Alessandro. História Oral como Arte da Escuta. São Paulo: Letra e Voz, 2016.

THOMPSON, Paul. The Voice of the past: oral history, 3. ed. Oxford, UK: Oxford University, 2000.

TONKIN, Elisabeth. Narrating our Pasts: the social construction of oral history. Cambridge, UK: Cambridge University, 1992.

WORCMAN, Karen e Jesus Vasquez Pereira (org.). História Falada: memória, rede e mudança social. São Paulo: SESC SP: Museu da Pessoa: Imprensa Oficial do Estado de São Paulo, 2006.

WORCMAN, Karen et GARDE-HANSEN, Joanne. Social Memory Technology: Theory, Practice, Action. New York: Routledge, 2016.

\section{Dados dos AUtores}

Karen Worcman

Historiadora, doutoranda pelo Programa de Pós-graduação Diversitas, da Faculdade de Filosofia, Letras e Ciências Humanas da Universidade de São Paulo. Fundadora e Diretora do Museu da Pessoa desde 1991.

Contato: karen@museudapessoa.net

\section{André Oliveira Costa}

Psicanalista, pós-doutorando pelo Programa de Pós-graduação Diversitas, da Faculdade de Filosofia, Letras e Ciências Humanas da Universidade de São Paulo, bolsista FAPESP (N . 2015/04897-0).

Contato: androlicos@gmail.com

Submetido em: 20-8-2017

Aceito em: 22-2-2018 